\title{
LIPID CHANGES AND SENSORY QUALITY OF WHOLE- AND GUTTED RAINBOW TROUT DURING STORAGE IN ICE
}

\author{
Anna KOEAKOWSKA*, Ludmiła ZIENKOWICZ, Zdzisław DOMISZEWSKI, \\ Grzegorz BIENKIEWICZ
}

Division of Food Quality, Agricultural University of Szczecin, Poland

Kołakowska A., Zienkowicz L., Domiszewski Z., Bienkiewicz G. 2006. Lipid changes and sensory quality of whole- and gutted rainbow trout during storage in ice. Acta Ichthyol. Piscat. 36 (1): 39-47.

Background. The aquaculture rainbow trout may be a valuable source of long chain n-3 polyunsaturated fatty acid (LC n-3 PUFA). In the retail these fish are mainly present as a whole or gutted. The present study was aimed at comparing changes occurring in lipids of whole and gutted rainbow trout stored in ice.

Materials and Methods. The analysis were performed after 0, 3, 7, and 14 days of storage in ice at $2^{\circ} \mathrm{C}$ and the following assays were carried out: proximate composition; lipid composition high pressure liquid chromatography (HPLC); fatty acid composition gas chromatography /mass spectrometry (GC/MS) by direct tissue saponification; contents of lipids extracted, using the Bligh-Dyer technique; UV-VIS, IR, and fluorescence lipid spectra; peroxide value (PV); anisidine value (AsV); and acid value (AC).

Results. Gutting prior to storage made it possible to extend the sensory shelf-life by about $2-3$ days and affected the quantitative fatty acid composition and oxidation level during storage in ice. The rainbow trout lipids are resistant to oxidation; oxidation product decomposition rather than lipid oxidation proceeds during storage, the decomposition being more intensive in whole than in gutted fish. It is only when the fish lose their eating quality ( 2 weeks) that a small increase in the level of oxidation occurs, accompanied by an about $15 \%$ loss of n-3 PUFA and a $20 \%$ loss of DHA, but only in the whole fish.

Conclusion. Gutting rainbow trout prior to storage in ice is appropriate by the extending the shelf-life by about 2-3 days and keeping stable amount of n-3 PUFA during 2 weeks of storage.

Keywords: rainbow trout, freshness, fish lipids, fatty acid, n-3 PUFA, lipid oxidation

\section{INTRODUCTION}

Cultured rainbow trout are marketed as whole fish. Supermarkets and retail stores usually sell them as gutted fish and/or fillets. In the catering industry, too, the fish are most frequently stored gutted before use. The quality of post-mortem fish, even if immediately chilled and stored under controlled cooling conditions, rapidly worsens and the fish deteriorate. Biochemical, microbiological, and sensory changes in numerous marine fish species have already been described in detail (e.g., Connell and Howgate 1968, Gould and Peters 1971, Huss 1988, Sikorski et al. 1990, Ólafsdóttir et al. 1997, Sikorski 2004). Much less information on freshwater cultured fish is available (Regenstein 1996).

Sensory characteristics have a major effect on the acceptance and market value of the product. The shelf-life of iced rainbow trout, as estimated by sensory analysis, amounts to about 14 days (Dawood et al. 1986, Berik and
Varlık 1999, Fik and Surówka 2004, Özogul et al. 2006). Based on sensory and microbiological analyses, Chytiri et al. (2004) estimated by routine (EC grading of raw fish and $0-10$ acceptability scale of cooked) the shelf-life of iced, whole, ungutted rainbow trout to be $15 / 16$ days, the shelf-life of fillets being 10/12 days. Rodríguez et al. (1999) studied sensory characteristics and biochemical changes ( $\mathrm{K}$ value, biogenic amines) with storage for up to 12 days in ice without gutting, after gutting, and in vacuum packing. They found acceptable freshness (overall score $>1.5$ included colour, odour, texture, flavour score in five-point scale with weightiness factor) to be maintained for five days in gutted and ungutted fish and for six days in vacuum-packed fish. Breakdown products of ATP are an objective indicator of freshness particularly recommended for rainbow trout (Hattula and Kiesvaara 1995, Tanimoto et al. 1999, Regenstein 1996, Özogul et al. 2006) 
The fish are a unique source of long chain (LC) n-3 PUFA, indispensable for correct development and functioning of human body (Lands 1997, Kołakowska et al. 2003). The cultured rainbow trout LC n-3 PUFA contents depend on the amount and composition of feed (Kiessling et al. 2001, Barrado et al. 2003, Kołakowska et al. 2003, Domiszewski and Kołakowska 2005) and on culture regime. Low temperature acclimatisation (Sellner and Hazel 1982, Ingemansson et al. 1993) and transfer to seawater (Haliloğlu et al. 2004) result in an increase in n-3 PUFA. Increasing the n-3 PUFA content in cultured fish via feeding requires a simultaneous antioxidant protection, e.g., by administering vitamin $\mathrm{E}$ and carotenoids (Aghtar et al 1996). Lipid oxidation results in deterioration of sensory quality and reduction of nutritive value, including losses of indispensable PUFA and formation of toxic oxidation products (Frankel 1998, Kołakowska 2003, Kamal-Eldin and Pokorny 2005). Undesirable changes in rainbow trout lipids have been studied in frozen fish (e.g., Ingemansson et al. 1992, 1995, Bjerkeng and Johnsen 1995). On the other hand, information on lipid changes during cool storage of rainbow trout is fragmentary and mostly based on the thiobarbituric acid reactive substances (TBARS) test and sensory evaluation of rancidity.

Clark et al. (1999) followed the effects of cantaxanthin on TBARS formation in minced rainbow trout meat at $4{ }^{\circ} \mathrm{C}$ for 6 days. Aghtar et al. (1996) used TBARS in their study on lipid oxidation in rainbow trout fillets stored at $4{ }^{\circ} \mathrm{C}$ (or frozen stored) in relation to combinations of antioxidants added to feed. Chaiyapechara et al. (2003) followed the effects of fish oil feed enrichment. Giménez et al. (2002) applied TBARS and sensory evaluation to study effects of overwrap, vacuum, and modified atmospheres on biochemical and microbiological changes in rainbow trout stored at $1^{\circ} \mathrm{C}$. Chytiri et al. (2004) compared TBARS changes in ungutted trout and in fillets during storage in ice. The fillet TBARS values were higher in fillets than those in ungutted fish.

The present study was aimed at comparing changes occurring in lipids of whole and gutted rainbow trout stored in ice.

\section{MATERIALS AND METHODS}

The cultured rainbow trout, Oncorhynchus mykiss, were harvested $(50 \mathrm{~kg})$ on 1 March 2005 . The individual fish weights ranged from 485 to $550 \mathrm{~g}$. The fish were obtained from a farm at Chełpia and delivered to the in PVC boxes in ice. They were rinsed and divided between the experimental treatment groups. The fish in one group were gutted, rinsed, and left to drip. Subsequently, the whole and gutted fish were placed in PVC boxes in ice with perforation bottom, ice being additionally placed on top of the fish batch; they were kept at $2 \pm 0.5^{\circ} \mathrm{C}$. The ratio of fish to ice was $3: 1$. The gutted fish were placed gut cavity down. The storage temperature was checked daily and additional ice was added every few days. The fish for assays were randomly selected when fresh (The day of slaughter, $2-3 \mathrm{~h}$ after capture was defined as day 0 ) as well as after 3,6, and 14 days of storage. Each time five whole and five gutted fish were selected; two fish of each treatment were subjected to sensory evaluation, while chemical assays were performed on three fish.

Sensory evaluation was performed by 7 member trained panellists following ISO 5496; the evaluation involved freshness, visual appearance (of eyes, viscera, gills, etc.), and odour of gills and viscera in accordance with EU standards (Anonymous 1996) and demerit points (Bremner 1985) on raw and cooked fish, using a 5-point intensity scale applied to the following characteristics: overall quality, appearance, smell, tastefulness, texture, and flavour profile. To be used in the other assays, the fish were filleted and ground with skin on by means of an electric meat grinder with a $2 \mathrm{~mm}$ diameter cutting plate (Zelmer, Poland).

The following parameters were determined: water content (drying at $105^{\circ} \mathrm{C}$ for $12 \mathrm{~h}$ ) according to the ISO 1442. Total nitrogen was determined with the Kjeldahl method, in a Kjeltec System 1026 (Tecator, Sweden) instrument. The protein content was calculated using a conversion factor of $6.25 .5 \%$ trichloroacetic acid (TCA) end concentration was used for deproteinisation of the sample.

Lipid extraction was performed using the Bligh-Dyer procedure (Bligh and Dyer 1959). The lipid content was determined gravimetrically, by evaporating a defined amount of extract. Lipid classes were determined using HPLC on a Waters apparatus equipped with a gradient pump Waters 600 and detector PDA 996. Separation was effected in a Lichrosphere Si $60250 \times 4.6$ column MERCK Germany with mobile phase consisting of hexane: 2-propanol: acetate buffer at $\mathrm{pH} 4.66(8: 8: 1 \mathrm{v} / \mathrm{v} / \mathrm{v})$; detection was at $\lambda=208 \mathrm{~nm}$. Chloroform lipid extracts were prepared by vacuum evaporating the solvent at $35^{\circ} \mathrm{C}$ and dissolving, prior to assay, in the mobile phase. Fatty acid composition was determined by gas chromatography coupled with mass spectrometry (GC/MS) using a Hewlett Packard II model 5890 USA, (SP 2560 capillary column $100 \mathrm{~m} \times 0.25 \mathrm{~mm} ; 0.20 \mathrm{~mm})$ SUPELCO. Oven temperature was $140(5 \mathrm{~min})$ to $240^{\circ} \mathrm{C}$ at $4^{\circ} \mathrm{C} \cdot \mathrm{min}^{-1}$. The fatty acid methyl esters (FAME) were prepared by direct saponification of the fish tissue (Domiszewski 2000) and chromatographic analysis was described previously (Kołakowska and Szczygielski 1994). UV-VIS (Pye-Unicam SP-6500, England), FT-IR spectra $\left(700-4000 \mathrm{~cm}^{-1}\right)$ MultiReflection HATR Swap-Top, MATSON [USA], and fluorescence (Hitachi Japan spectrofluorometer, Ex $365 \mathrm{~nm}$ Em $436 \mathrm{~nm}$ lipid spectra were analysed in chloroform layer of Bligh-Dyer lipid extracts using $1 \mathrm{~cm}$ quartz cell. Peroxide value (PV) of lipids was determined with the thiocyanate technique according to the Polish Standard BN-74/8020-07. Anisidine value (AsV) was determined according to ISO 6885:1988. Acid value (AV) was determined by titration Polish Standard method PN-83/A-86747. Lipid susceptibility to oxidation was determined by exposing lipids, in a thin layer, to UV, $\lambda=234 \mathrm{~nm}$ for $180 \mathrm{~min}$ the details were described Kołakowska (1991), and checking the level of oxidation with PV and AsV. 
The results presented in the tables and figures are means of three replicate assays performed on the same lipid extracts. Statistical treatment of the results involved analysis of variance and a post-hoc test, the Least Significant Difference being determined at the probability level of $P<0.05$. The analysis was run using the STATISTICA computer package StatSoft Krakow, Poland.

\section{RESULTS}

The rainbow trout sensory quality was found to depend $(P<0.05)$ on time of storage. A stronger relationship of most sensory indicators with time of storage was found in whole than in gutted fish. The preliminary fish treatment also affected the course of sensory changes (Fig. 1, Table $1)$. Deterioration of whole fish was found to increase linearly with time of storage $\left(R^{2}=0.992\right)$ while it in the gutted fish was less correlated with time of storage $R^{2}=0.947$ as late as after 3 days of storage, the increase being them more rapid them whole fish (Fig. 1). The sensory changes of raw fish were accompanied by reduction of meat tastefulness. After 3 days of storage, intensity of sweet taste and taste typical of cooked fish was reduced, the reduction being more distinct in the gutted than in whole fish. During further storage, however, a significantly higher tastefulness was found in the gutted than in whole fish (Fig. 2).

The significant relationship between sensory changes and time of storage $(P<0.05)$ allowed identification of individual quality classes, determined with EU criteria and demerit points (Table 1). The gutted fish retain their acceptable eating quality for about 3 days longer than the whole fish. As shown by the data in Table 1 using the EU criteria the gutted fish should be rejected after 25 days, while the panel evaluation showed the fish to be inconsumable earlier, after 21 days.

Data on proximate composition (Table 2) evidence significant differences between crude protein and lipid contents in stored whole and gutted fish. No significant differences between whole and gutted fish were found in their lipid fraction composition determined using HPLC \% area or in AV changes during storage (Table 3). The significantly higher FFA content in the whole fish after 14 days of storage could be noticed by comparing the areas of the free fatty acid (FFA) fractions (Fig. 3), and along with their percentages.

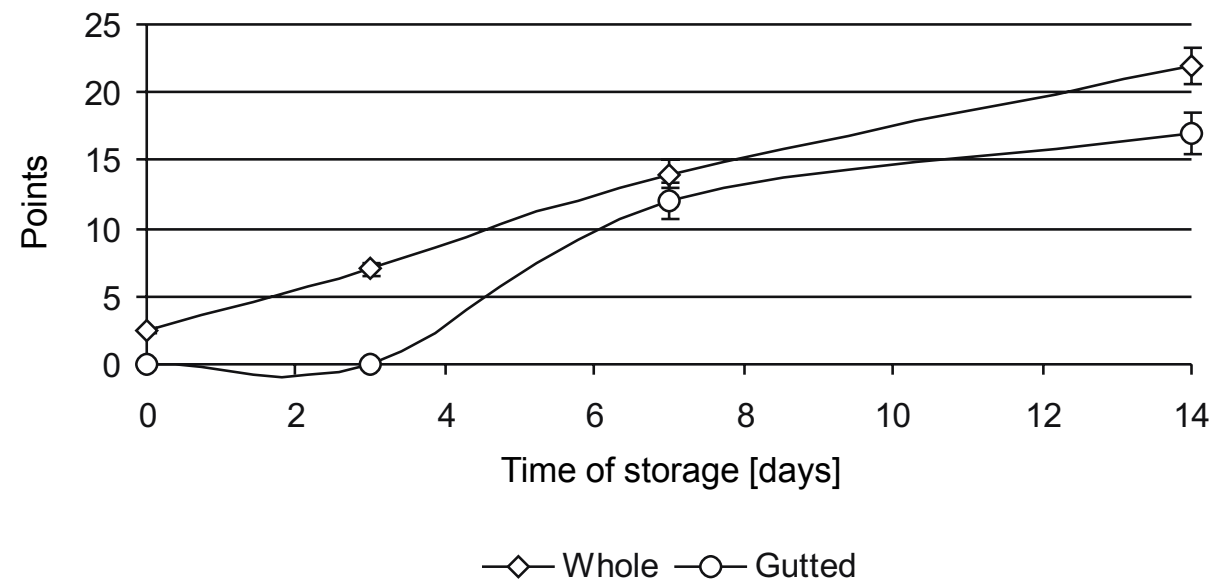

Fig. 1. Change of demerit points of whole and gutted rainbow trout during storage in ice

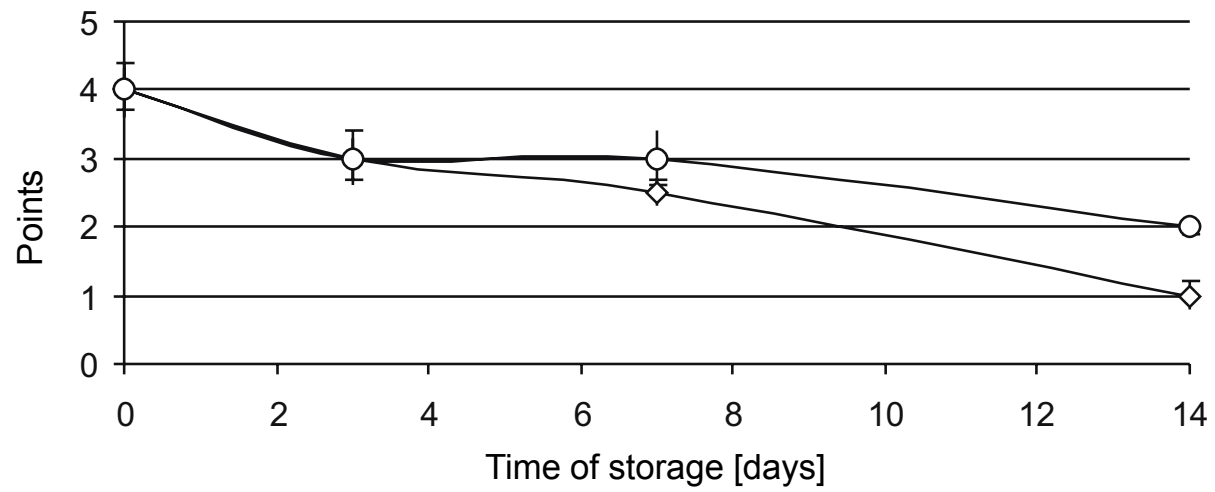

$\checkmark$ Whole $\multimap-$ - Gutted

Fig. 2. Changes in tastefulness of whole and gutted rainbow trout during storage in ice 
Table 1

Shelf-life in days of iced whole and gutted rainbow trout

\begin{tabular}{lccccc}
\hline $\begin{array}{l}\text { Demerit points } \\
\text { Grade }\end{array}$ & Whole & Gutted & & WC system \\
Vhole & Gutted \\
\hline Very good $<5$ & 1.0 & 4 & Extra & 2 & 3 \\
Good $<18$ & 10.5 & 13.5 & A & 11 & 14 \\
Fair $<24$ & 15 & 17.8 & B & 17.7 & 25 \\
Poor, inconsumable $>24$ & $>15$ & $>18$ & C & & \\
\hline
\end{tabular}

Table 2

Proximate composition of whole and gutted rainbow trout stored in ice

\begin{tabular}{cccccccccc}
\hline & \multicolumn{2}{c}{$\begin{array}{c}\text { Water } \\
{[\% \text { w.w. }]}\end{array}$} & \multicolumn{2}{c}{ w.w. } & \multicolumn{2}{c}{ Protein $[\%]$} & \multicolumn{2}{c}{$\begin{array}{c}\text { Lipids } \\
{[\% \text { w.w. }]}\end{array}$} \\
\cline { 2 - 10 } Days & Whole & Gutted & Whole & Gutted & Whole & Gutted & Whole & Gutted \\
\cline { 2 - 10 } & 70.14 & 70.14 & 21.43 & 21.43 & 71.77 & 71.77 & 7.86 & 7.86 \\
0 & $74.31^{\mathrm{b}}$ & $67.20^{\mathrm{a}}$ & $18.2^{\mathrm{a}}$ & $21.74^{\mathrm{b}}$ & $71.22^{\mathrm{a}}$ & $73.27^{\mathrm{b}}$ & $8.11^{\mathrm{a}}$ & $10.98^{\mathrm{b}}$ \\
3 & $71.29^{\mathrm{a}}$ & $71.12^{\mathrm{a}}$ & $19.83^{\mathrm{a}}$ & $19.04^{\mathrm{a}}$ & $65.93^{\mathrm{a}}$ & $76.51^{\mathrm{b}}$ & $10.14^{\mathrm{b}}$ & $8.85^{\mathrm{a}}$ \\
7 & $71.37^{\mathrm{a}}$ & $71.72^{\mathrm{a}}$ & $17.74^{\mathrm{a}}$ & $19.01^{\mathrm{b}}$ & $66.03^{\mathrm{a}}$ & $68.71^{\mathrm{b}}$ & $10.54^{\mathrm{a}}$ & $11.69^{\mathrm{b}}$ \\
\hline
\end{tabular}

ab, significant difference at $P<0.05$ in whole and gutted fish in blocks; w.w., wet weight; d.m., dry mass

Table 3

Lipid composition [\% fractions] and acid value in whole and gutted rainbow trout stored in ice

\begin{tabular}{cllccccccc}
\hline \multirow{2}{*}{ Days } & \multicolumn{2}{c}{ NL } & \multicolumn{2}{c}{ FFA } & \multicolumn{2}{c}{ PL } & \multicolumn{2}{c}{ AV } \\
& Whole & Gutted & Whole & Gutted & Whole & Gutted & Whole & Gutted \\
\hline 0 & 92.4 & 92.4 & 1.98 & 1.98 & 5.62 & 5.62 & 5.89 & 5.89 \\
3 & $92.51^{\mathrm{a}}$ & $93.04^{\mathrm{a}}$ & $2.01^{\mathrm{a}}$ & $2.20^{\mathrm{a}}$ & $5.48^{\mathrm{a}}$ & $4.76^{\mathrm{a}}$ & $5.08^{\mathrm{a}}$ & $4.29^{\mathrm{a}}$ \\
7 & $94.34^{\mathrm{a}}$ & $93.93^{\mathrm{a}}$ & $1.27^{\mathrm{a}}$ & $1.40^{\mathrm{a}}$ & $4.38^{\mathrm{a}}$ & $4.67^{\mathrm{a}}$ & $6.13^{\mathrm{a}}$ & $7.31^{\mathrm{a}}$ \\
14 & $93.46^{\mathrm{a}}$ & $92.95^{\mathrm{a}}$ & $2.35^{\mathrm{a}}$ & $2.79^{\mathrm{a}}$ & $4.19^{\mathrm{a}}$ & $4.26^{\mathrm{a}}$ & $6.39^{\mathrm{a}}$ & $6.40^{\mathrm{a}}$ \\
\hline
\end{tabular}

ab, significant difference at $P<0.05$ in whole and gutted fish in blocks; NL, neutral lipids; FFA, free fatty acids; PL, phospholipids; $\mathrm{AV}$, acid value

During storage in ice at $2{ }^{\circ} \mathrm{C}$ the rainbow trout were resistant to oxidation. The highest $\mathrm{PV}$ and $\mathrm{AsV}$ were recorded in the lipids of the fresh fish and those stored for 2 weeks; in the latter case, however, the values were lower than those found at the start Fig. 4.

The number of fatty acid conjugated bonds was higher in the fresh fish as well. No increase in lipid fluoresce was observed during storage; the amount of fluorophores with maximum emission at $436 \mathrm{~nm}$ was lower after 2 weeks of storage than in the fresh fish (Table 4).

Gutting the fish prior to storage was found to have significantly affected the lipid oxidation level (Fig. 4). Generally, lipids of the gutted rainbow trout were more oxidised than those of the whole fish stored for an identical period. They contained more peroxides during the first week of storage and more secondary products of oxidation throughout the period of storage, and - except for the 7th day of storage - more conjugated diene and triene bonds and more fluorophores (Table 4). After 7 days of storage, a fish oil smell was detected in the cooked fish, the smell being more pronounced in the gutted than in the whole fish ( 2 and 1 point, respectively, on the 5-point intensity scale). The typically rancid taste was detectable, at the threshold level only by some panellists, even after 2 weeks of storage.

An indirect proof of rainbow trout lipid stability under the storage conditions tested is provided by changes in fatty acid composition (Table 5). In the fresh rainbow trout, lipids contained $25 \%$ saturated fatty acids (SFA), 50\% monounsaturated fatty acids (MUFA), and 25\% (PUFA), the n-3 PUFA contributing 19\% (Table 5). The time of storage and manner of treatment (gutting vs. whole) af- 
fected the fatty acid composition. The ungutted fish n-3 in n-3 PUFA in the gutted fish was higher (coefficient of PUFA content decreased very slowly, but consistently, variation of $12.22 \%$, as compared to $6.09 \%$ in the whole with time of storage $P<0,05$; after 2 weeks, the n-3 PUFA fish). After 2 weeks of storage, however, no n-3 PUFA content was about $15 \%$ lower, compared to the maximum losses, including the most sensitive DHA, were observed, content recorded after 3 days of storage; the DHA content relative to the levels in the fresh fish. decreased at that time by almost $20 \%$.

Changes in n-3 PUFA in gutted fish were found to cor-

The fatty acid losses were effected, albeit not signifi- relate non-significantly with lipid oxidation so, with the cantly, by the peroxide content (Table 6). The variability diene amount (Table 6).

Table 4

Changes of dienes, trienes and fluorescence of lipids in whole and gutted rainbow trout during storage in ice

\begin{tabular}{|c|c|c|c|c|c|c|c|c|}
\hline \multirow[t]{2}{*}{ Days } & \multicolumn{2}{|c|}{$\begin{array}{c}\text { Dienes } \\
{[1 \mathrm{~cm} / 1 \%]}\end{array}$} & \multicolumn{2}{|c|}{$\begin{array}{c}\text { Trienes } \\
{[1 \mathrm{~cm} / 1 \%]}\end{array}$} & \multicolumn{2}{|c|}{$\begin{array}{c}\mathrm{Em}_{\max } \\
{[1 \mathrm{~cm} / 1 \%]}\end{array}$} & \multicolumn{2}{|c|}{$\begin{array}{c}\mathrm{Em}_{436} \\
{[1 \mathrm{~cm} / 1 \%]}\end{array}$} \\
\hline & Whole & Gutted & Whole & Gutted & Whole & Gutted & Whole & Gutted \\
\hline 0 & 0.647 & 0.647 & 0.845 & 0.845 & 1562 & 1562 & 1562 & 1562 \\
\hline 3 & $0.633^{\mathrm{a}}$ & $0.488^{b}$ & $0.819^{a}$ & $0.922^{b}$ & $1599^{a}$ & $1224^{b}$ & $1599^{a}$ & $1215^{b}$ \\
\hline 7 & $0.477^{a}$ & $0.576^{\mathrm{b}}$ & $0.668^{a}$ & $0.860^{\mathrm{b}}$ & $1052^{a}$ & $1341^{b}$ & $1052^{\mathrm{a}}$ & $1341^{b}$ \\
\hline 14 & $0.431^{\mathrm{a}}$ & $0.403^{\mathrm{a}}$ & 0.780 & 0.726 & $1305^{\mathrm{a}}$ & $741^{b}$ & $1308^{a}$ & $741^{b}$ \\
\hline
\end{tabular}

ab, significant difference at $P<0.05$ in whole and gutted fish in blocks

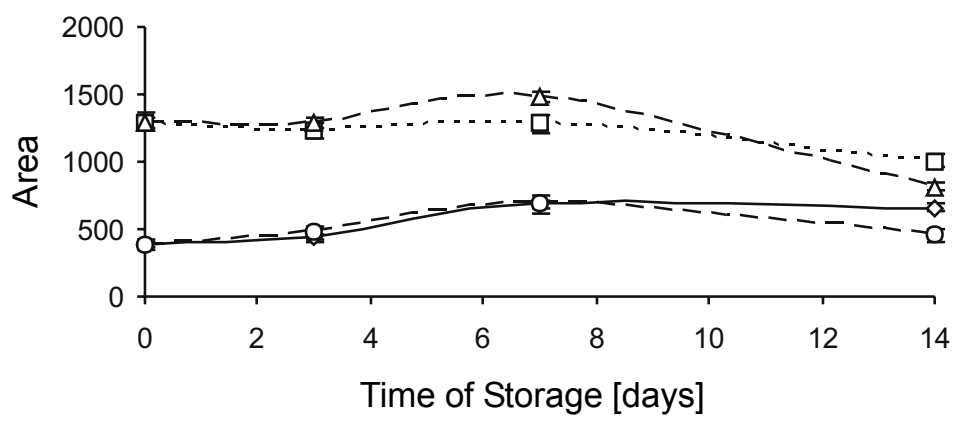

$\prec$ FFA w - - - - - PL w - - - FFA g - - - - PL g

Fig. 3. Changes in content fatty acid and phospholipid of whole and gutted rainbow trout during storage in ice; FFA, free fatty acids; PL, phospholipid; w, whole fish; g, gutted fish

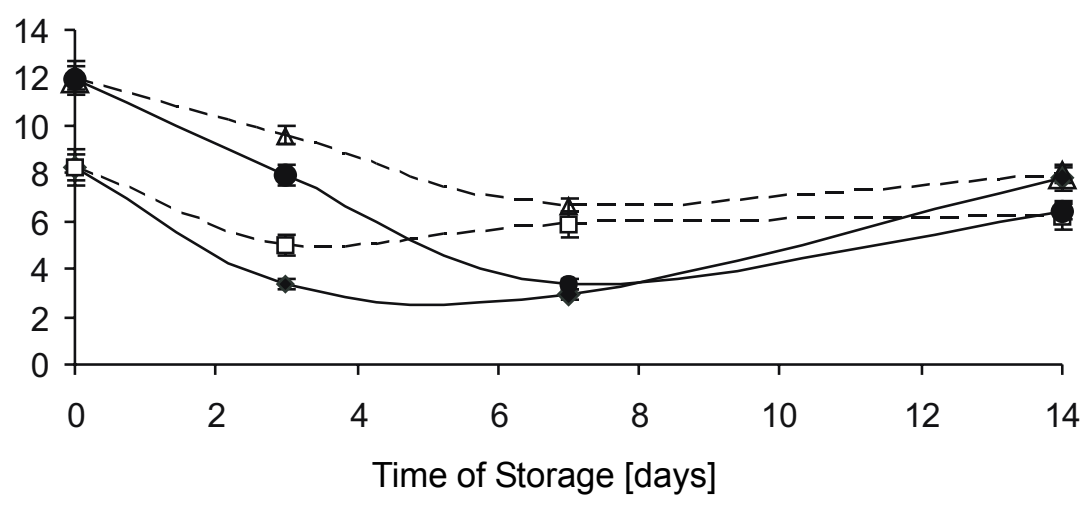

$\longrightarrow$ PV w $--\square-P V g \longrightarrow$ AsV w $--\Delta-A s \vee g$

Fig. 4. Changes in $\mathrm{PV}\left[\mathrm{mgO}^{*} \cdot 100 \mathrm{~g}^{-1}\right.$ lipids $]$ and $\mathrm{AsV}$ of whole and gutted rainbow trout during storage in ice; PV, peroxide value; AsV, anisidine value; w, whole fish; g, gutted fish 
Fatty acids composition in whole and gutted rainbow trout stored in ice

\begin{tabular}{|c|c|c|c|c|c|c|c|}
\hline \multirow{3}{*}{ Fatty acid } & \multicolumn{6}{|c|}{ Day } & \\
\hline & 0 & & & & & \multicolumn{2}{|c|}{14} \\
\hline & Gutted & Whole & Gutted & Whole & Gutted & Whole & Gutted \\
\hline C $14: 0$ & 5.47 & 4.84 & 4.44 & 5.07 & 4.46 & 4.89 & 5.30 \\
\hline C 15:0 & 0.13 & 0.18 & 0.18 & 0.22 & 0.19 & 0.20 & 0.19 \\
\hline C 15:0i & 0.24 & 0.32 & 0.32 & 0.36 & 0.34 & 0.79 & 0.31 \\
\hline C 16:0 & 16.13 & 13.65 & 14.59 & 14.04 & 13.50 & 14.30 & 13.48 \\
\hline C 17:0 & 0.11 & 0.09 & 0.12 & 0.13 & 0.13 & 0.12 & 0.06 \\
\hline C $16: 1$ & 6.56 & 6.24 & 6.29 & 6.74 & 6.44 & 6.31 & 6.75 \\
\hline C 17:0i & 0.12 & 0.17 & 0.19 & 0.19 & 0.20 & 0.20 & 0.16 \\
\hline C 17:1 & 0.12 & 0.24 & 0.23 & 0.27 & 0.26 & 0.30 & 0.20 \\
\hline C 18:0 & 2.38 & 2.42 & 2.93 & 2.57 & 2.73 & 3.37 & 2.21 \\
\hline C $18: 1$ & 1.72 & 1.29 & 9.13 & 0.90 & 1.34 & 0.98 & 2.41 \\
\hline C $18: 1$ & 14.87 & 14.04 & 9.64 & 14.91 & 15.48 & 15.01 & 13.71 \\
\hline C $18: 1$ & 2.69 & 2.82 & 1.61 & 2.87 & 2.91 & 2.66 & 2.85 \\
\hline C $18: 2 n-6$ & 6.49 & 6.25 & 6.04 & 6.37 & 6.44 & 5.41 & 6.98 \\
\hline C 20:1 & 12.59 & 13.75 & 13.96 & 13.66 & 13.46 & 13.43 & 11.48 \\
\hline C $18: 3 n-3$ & 1.48 & 1.14 & 0.69 & 0.70 & 1.25 & 1.02 & 1.85 \\
\hline C $18: 4 n-3$ & 1.50 & 1.63 & 1.27 & 1.68 & 1.46 & 1.25 & 2.00 \\
\hline C $20: 2 n-6$ & 0.29 & 0.63 & 0.64 & 0.68 & 0.71 & 0.63 & 0.68 \\
\hline C 22:1 & 10.81 & 11.78 & 12.14 & 10.96 & 11.16 & 12.81 & 10.09 \\
\hline C $20: 3 n-3$ & 0.09 & 0.21 & 0.18 & 0.18 & 0.23 & 0.22 & 0.17 \\
\hline C $20: 4 n-6$ & 0.09 & 0.25 & 0.24 & 0.27 & 0.26 & 0.27 & 0.27 \\
\hline C $20: 4 n-3$ & 0.78 & 1.09 & 1.05 & 1.19 & 1.32 & 1.14 & 1.13 \\
\hline C $20: 5 n-3$ & 4.21 & $4.27^{b}$ & $3.40^{\mathrm{a}}$ & $4.24^{b}$ & $3.83^{\mathrm{a}}$ & $3.84^{\mathrm{a}}$ & $4.55 b$ \\
\hline C $24: 1$ & 0.20 & 0.61 & 0.63 & 0.58 & 0.63 & 0.74 & 0.41 \\
\hline C $22: 5 n-3$ & 0.75 & 1.42 & 1.32 & 1.48 & 1.62 & 1.39 & 1.32 \\
\hline C $22: 6 n-3$ & 10.17 & $10.67^{b}$ & $8.77^{\mathrm{a}}$ & $9.75^{\mathrm{a}}$ & $9.66^{\mathrm{a}}$ & $8.73^{\mathrm{a}}$ & $11.44 \mathrm{~b}$ \\
\hline$\Sigma \mathrm{SFA}$ & 24.57 & $21.67^{\mathrm{a}}$ & $22.77^{\mathrm{a}}$ & $22.57^{\mathrm{a}}$ & $21.54^{\mathrm{a}}$ & $23.86^{\mathrm{b}}$ & $21.72 \mathrm{a}$ \\
\hline$\Sigma$ MUFA & 49.57 & $50.78^{a}$ & $53.63^{b}$ & $50.89^{a}$ & $51.68^{a}$ & $52.24^{\mathrm{b}}$ & $47.91 \mathrm{a}$ \\
\hline$\Sigma$ PUFA & 25.85 & $27.55^{b}$ & $23.60^{\mathrm{a}}$ & $26.54^{\mathrm{a}}$ & $26.78^{a}$ & $23.90^{\mathrm{a}}$ & $30.38 b$ \\
\hline$\sum n-3$ & 18.98 & $20.42^{b}$ & $16.69^{a}$ & $19.22^{\mathrm{a}}$ & $19.37^{\mathrm{a}}$ & $17.59^{a}$ & $22.45 b$ \\
\hline$\sum n-6$ & 6.87 & 7.13 & 6.92 & 7.32 & 7.41 & 6.31 & 7.92 \\
\hline$\sum n-6 / \sum n-3$ & 0.36 & 0.35 & 0.41 & 0.38 & 0.38 & 0.36 & 0.35 \\
\hline
\end{tabular}

ab, significant difference in each row at $P<0.05$ in whole and gutted fish; SFA, saturated fatty acids; MUFA, monounsaturated fatty acids; PUFA, polyunsaturated fatty acids; Whole /Gutted, the whole fish were subsequently gutted)

\section{Table 6 DISCUSSION}

Correlation $\left(R^{2}\right)$ between n-3 PUFA lipid oxidation indices between whole and gutted fish

\begin{tabular}{lrr}
\hline Index & Whole & Gutted \\
\hline PV & -0.699 & 0.259 \\
AsV & 0.091 & -0.364 \\
Diene & 0.235 & -0.694 \\
Treiene & 0.074 & -0.201 \\
Fluorescence & 0.600 & -0.505 \\
\hline
\end{tabular}

The observed sensory changes occurring during rainbow trout storage in ice were consistent with descriptions presented by other authors (Connell and Howgate 1968, Gould and Peters 1971, Sikorski et al. 1990, Ólafsdóttir et al. 1997, Sikorski 2004, Chytiri et al. 2004). The increasing deterioration of the raw fish was correlated with reduced tastefulness of the cooked fish, similarly to the findings reported by Luten and Martinsdottir (1997). The reduction in tastefulness was caused primarily probably by nucleotide decomposition (Huss 1988, Sikorski et al. 1990, Regenstein 1996). The changes in tastefulness and taste 
profile observed in this study are similar to the changes in nucleotides in ice-stored rainbow trout meat reported by Hattula and Kiesvaara (1996), Rodríguez et al. (1999), and Tanimoto et al. (1999).

Compared to the literature data on cultured rainbow trout (Dawood et al. 1986, Berik and Varlık 1999, Fik and Surówka 2004, Özogul et al. 2006), the shelf-lives determined in this study are longer. The discrepancy may be due to the lower storage temperature $\left(2^{\circ} \mathrm{C}\right)$, compared to $4-5^{\circ} \mathrm{C}$ applied by the authors referred to. Even small temperature differences affect the rate of post-mortem changes in fish (Sikorski 2004), including nucleotide decomposition in rainbow trout (Poli et al. 1996). In addition, the studies referred to involved storage of fillets; as demonstrated by Chitiri et al. (2004), sensory and microbiological changes in ice-stored rainbow trout proceeded faster in fillets than in whole fish. As shown by this study, the shelf-life of the gutted rainbow trout is longer than that of whole fish. The sensory properties were closely correlated with time of storage, but the course of changes differed between the ungutted and gutted fish. Gutting resulted in a delay in autolytic changes and, hence, in extension of shelf-life by at least 2-3 days, compared to that of the whole fish. Autolysis in the whole fish was more extensive due to the activity of exopeptidases diffused from internal organs to the muscle tissue prior to the preliminary treatment (Kołakowski et al., unpublished).

The small, albeit significant $(P<0.05)$ reduction in the crude protein (total nitrogen) content as a result of storage could have been caused by washing out of nitrogen compounds during rinsing of the fish. The stored whole fish were rinsing after gutting before preparing of filet for analysis.

Storage in ice facilitates lipid extraction from the muscle tissue with the Bligh-Dyer technique (Kołakowska at al. 2006), as evidenced by the higher lipid contents in the stored fish, compared to the fresh ones assayed directly after harvesting. A 2-week-long storage resulted in accumulation of less than $3 \%$ of FFA; no effect of gutting on lipolysis could be detected. These results indicated probably a low activity of lipases, both those in tissues and in the of rainbow trout, compared to the activity in marine fish as revived by Kołakowska et al. 2003

The rainbow trout stored in ice at $2^{\circ} \mathrm{C}$ were resistant to oxidation. The level of lipid oxidation depended on whether the fish were stored whole or gutted; that was true for all the oxidation indices used. For most of the storage time, more oxidised lipids were occurring in the gutted fish; it was only after 2 weeks of storage that the whole fish lipids were slightly more oxidised than those in the gutted fish.

A higher rate of oxidation of lipids in carcasses than in whole fish was demonstrated earlier in Baltic herring stored at $-22^{\circ} \mathrm{C}$ (Kołakowska 1979); the TBA content was higher in rainbow trout fillets kept in ice than in whole fish (Chytiri et al. 2004). The cause of a better stability of lipids in whole than in gutted fish is possibly due to the fact that it is harder for oxygen to penetrate into whole fish and there may be a higher accumulation of proteolysis products, acting as antioxidants, with time of storage (Je et al. 2005). Because the rainbow trout studied showed no increased lipid oxidation during the first week of storage (a decrease relative to the initial level being observed), it may be suggested that the muscle tissue of rainbow trout, particularly in the whole fish, was predominantly a site of antioxidant over prooxidant activity at that time (Han and Liston 1989).

An indirect proof of the rainbow trout lipid stability under the storage conditions applied was provided by the changes in fatty acid composition: significant losses of the most labile long-chain n-3 PUFA were detected quite late, i.e., after two weeks of storing the whole fish when a small increase in lipid oxidation was recorded and when the fish lost their sensory eating quality. The data on the rainbow trout fatty acid composition and fatty acid stability obtained in this study are consistent with our earlier results (Kołakowska et al. 2000, 2006) and do not contradict the numerous earlier papers reporting the rainbow trout fatty acid composition, which was studied in connection with effects of feeds and other aquaculture conditions on lipid contents and composition. Fatty acid composition does depend on the feed used; that was confirmed in the farm that supplied fish for this study (Domiszewski and Kołakowska 2005, Kołakowska et al. 2006). Feed may also affect the post-mortem lipid oxidation (Kołakowska et al. 2003). Particular attention might be paid to the carotenoid content, because lipid stability is thought to be particularly dependent on astaxanthin (Andersen et al. 1990, Bjerkeng and Johnsen 1995, Aghtar et al. 1996, Jensen et al. 1998).

The study showed that the rainbow trout stored in ice at low temperature are edible for at least 2 weeks; if they are gutted prior to storage, the eating quality may be extended by $2-3$ days. Gutting affects changes in fatty acids and the course of lipid oxidation during storage in ice. The rainbow trout lipids were highly resistant to oxidation. The whole fish lipids usually showed a lower level of oxidation, compared to the lipids of the gutted fish stored for an identical period of time which could be explained by a higher antioxidant activity rather than in a higher rate of oxidation in gutted fish. A fillet with skin, obtained from the fish under study, was found to contain $1.73 \mathrm{~g} \mathrm{n}-3$ PUFA and did not lose the fatty acids even after a 2-week-long storage.

On the other hand, at the time when the whole fish loose their consumption suitability, after a period of storage, the n-3 PUFA and DHA losses may reach ca. 15\% and $20 \%$, respectively. Therefore, the results obtained allow the conclusion that cultured rainbow trout is a good source of n-3 PUFA, as a $50 \mathrm{~g}$ fillet contains, throughout its period of acceptable freshness, an n-3 PUFA daily dose at least equal to that recommended by International Society for the Study of Fatty Acid and Lipids (Anonymous 2004), the lipid oxidation level being low. 


\section{ACKNOWLEDGEMENTS}

We thank the State Committee for Scientific Research (KBN, Poland) for the financial support (Project No 3PO6T 060 25).

\section{REFERENCES}

Aghtar P., Gray J.I. Booren A.M., Cooper T.H. 1996. Effect of feed components on color and lipid stability of rainbow trout muscle during refrigerated and frozen storage. P. 164 In: IFT Annual meeting: book of abstracts.

Andersen H.J., Bertelsen G., Christophersen A. G., Ohlen A., Skibsted L.H. 1990. Development of rancidity in salmonoid steaks during retail display. A comparison of practical storage life of wild salmon and farmed rainbow trout. Zeitschrift für Lebensmitteluntersuchung und -Forschung 191 (2):119-122.

Anonymous 1996. Council Regulation (EC) No. 2406/96 of 26 November 1996 laying down common marketing standards for certain Fishery Products. Official Journal of the European Union OJ L (334, 23.12.1996): 1 - 24. http://eur-lex. europa.eu/LexUriServ/site/en/consleg/1996/R/01996R2406 -20050602-en.pdf

Anonymous 2004. Recommendations for intake of polyunsaturated fatty acids in healthy adults. Report of International Society for the Study of Fatty Acid and Lipids, Bringhton.

Barrado E., Jimenez F., Prieto F., Nuevo C. 2003. The use of fatty acid profiles of the lipids of the rainbow trout (Oncorhynchus mykiss) to differentiate tissue and dietary feed. Food Chemistry 81: 13-20.

Berik N., Varlık C. 1999. Kültür gökkuşagı alabalık (Oncorhynchus mykiss Walbaum, 1792) filetosunun soğukta depolanmas1. [Cold storage of cultured rainbow trout (Oncorhynchus mykiss Walbaum, 1792) fillet.] Turkish Journal of Veterinary and Animal Sciences 23 (2): 285-290. [In Turkish.]

Bjerkeng B., Johnsen G. 1995. Frozen storage quality of rainbow trout (Oncorhynchus mykiss) as affected by oxygen, illumination, and fillet pigment. Journal of Food Science $\mathbf{6 0}$ (2): 284-288.

Bligh E.G., Dyer W.J. 1959. A rapid method for total lipid extraction and purification. Canadian Journal of Biochemistry and Physiology 37: 911-917.

Bremner H.A. 1985. A convenient, easy-to-use, system for estimating the quality of chilled seafoods. Fish Processing Bulletin 7: 59-70.

Chaiyapechara S, Liu K.K.M., Barrows F.T., Hardy R.W., Dong F.M. 2003. Proximate composition, lipid oxidation, and sensory characteristics of fillets from rainbow trout, Oncorhynchus mykiss, fed diet containing 10\% to 30\% lipid. Journal of the World Aquaculture Society 34 (3): 266-277.

Chytiri S., Chouliara I., Savvaidis I.N., Kontominas M.G. 2004. Microbiological, chemical and sensory assessment of iced whole and filleted aquacultured rainbow trout. Food Microbiology 21: 157-165.

Clark T.H., Faustman C., Chan W.K.M., Furr H.C., Riesen J.W. 1999. Canthaxanthin as an antioxidant in a liposome model system and in minced patties from rainbow trout ( $\mathrm{On}$ corhynchus mykiss). Journal of Food Science 64 (6): 982 986.
Connell J.J., Howgate P.F. 1968. Sensory and objective measurements of the quality of frozen-stored haddock of different initial freshness. Journal of the Science of Food and Agriculture 19: $342-353$

Dawood A.A., Roy R.N., Williams C.S. 1986. Effect of delayed icing on the storage of life of rainbow trout. Journal of Food Technology 21: 159-166.

Domiszewski Z. 2000. Porównanie składu kwasów tłuszczowych lipidów rybnych przy zastosowaniuu zmydlania bezpośredniego i pośredniego $\mathrm{z}$ próby. [The comparison of fatty acids composition of fish lipids with the use of direct and indirect saponification of a sample.] P. 123. In: Streszczenia: XXIV Sympozjum Naukowe "Chromatograficzne metody badania związków organicznych" 7-9. czerwca 2000, Szczyrk, Poland. [In Polish.]

Domiszewski Z., Kołakowska A. 2005. Porównanie składu kwasów thuszczowych paszy i filetów pstraga. [A comparison of the fatty acid composition in the feed and trout fillets.] P. 153. In: XXXVI Sesja Naukowa Komitetu Nauk o Żywności PAN, 13-14 września 2005, Szczecin, Poland. [In Polish.]

Fik M., Surówka K. 2004. Autoproteolysis rate of rainbow trout muscle proteins. Nahrung/Food 48 (2): 104-109.

Frankel E.N. 1998. Lipid Oxidation. The Oily Press, Dundee, Scotland.

Giménez B. Roncalés P., Beltrán J. A. 2002. Modified atmosphere packaging of filleted rainbow trout. Journal of Science and Food Agriculture 82 (10): 1154-1159.

Gould E., Peters J.A. 1971. On the testing the freshness of frozen fish. Fishing News (Books), London.

Han T.J., Liston J. 1989. Lipid peroxidation protection factors in rainbow trout (Salmo gairdnerii) muscle cytosol. Journal of Food Science 54 (4): 809-813.

Hattula T., Kiesvaara M. 1996. Breakdown products of adenosine triphosphate in heated fishery products as an indicator of raw material freshness and storage quality. LebensmittelWissenschaft und-Technologie 29: 135-139.

Haliloğlu H.I., Bayir A., Sirkecjoğlu A.N., Aras N.M., Atamanalp M. 2004. Comparison of fatty acid composition in some tissues of rainbow trout (Oncorhynchus mykiss) living in seawater and freshwater. Food Chemistry 86: 55-59.

Huss H.H. 1988. Fresh fish-quality and quality changes. FAO Fisheries Series, No. 29, FAO, Rome

Ingemansson T., Kaufmann P., Petterson A. 1992. Lipid deterioration in frozen stored muscle tissue of rainbow trout $(\mathrm{On}$ corhynchus mykiss) in relation to water temperature and carotenoid content. Pp. 29-38. In: Huss H.H., Jakobsen M., Liston J. (eds.) Quality assurance in the fish industry. Elsevier Science Publishers, Amsterdam.

Ingemansson T., Olsson N.U., Kaufmann P. 1993. Lipid composition of light and dark muscle of rainbow trout (Oncorhynchus mykiss) after thermal acclimation: a multivariate approach. Aquaculture 113: 153-165.

Ingemansson T., Kaufmann P., Ekstrand B. 1995. Multivariate evaluation of lipid hydrolysis and oxidation data from light and dark muscle of frozen stored rainbow trout (Oncorhynchus mykiss). Journal of Agricultural and Food Chemistry 43: 2046-2052. 
Je J.-Y., Park P.-J., Kim S.-K. 2005. Antioxidant activity of a peptide isolated from Alaska pollack (Theragra chalcogram$m a$ ) frame protein hydrolysate. Food Research International 38 (1): 45-50.

Jensen C., Birk E., Jokumsen A., Skibsted L.H., Bertelsen G. 1998. Effect of dietary level of fat, $\alpha$-tocopherol and astaxanthin on colour and lipid oxidation during storage of frozen rainbow trout (Oncorhynchus mykiss) during chill storage of smoked trout. European Food Research and Technology 207: 189-196.

Kamal-Eldin A., Pokorny J. 2005. Analysis of lipid oxidation. AOCS Press, USA.

Kiessling A., Pickova J., Johansson L., ęsgćrd T., Storebakken T., Kiessling K-H. 2001. Changes in fatty acid composition in muscle and adipose tissue of farmed rainbow trout (Oncorhynchis mykiss) in relation to ration and age. Food Chemistry 73: 271-284.

Kołakowska A. 1979. Effect of initial processing on fat rancidity dynamics during storage of frozen fish. Bulletin de l'Institut International du Froid 59: 1184.

Kołakowska A. 1991. The oxidability of krill lipids. Polish Polar Research 12: 89.

Kołakowska A., Szczygielski M. 1994. Stabilization of lipids in minced fish by freeze texturization. Journal of Food Science 59: 88-90.

Kołakowska A., Szczygielski M., Bienkiewicz G., Zienkowicz L. 2000. Some of fish species as a source of n-3 polyunsaturated fatty acids. Acta Ichthyologica et Piscatoria 30 (2): 59-70.

Kołakowska A. 2003. Lipid oxidation in food systems. Pp. 133-166. In: Sikorski Z.E., Kołakowska A. (eds.) Chemical and functional properties of food lipids. CRC Press, Boca Raton.

Kołakowska A., Olley J., Dunstan G.A. 2003. Fish lipids. Pp. 221-264. In: Sikorski Z.E., Kołakowska A. (eds.) Chemical and functional properties of food lipids. CRC Press, Boca Raton.

Kołakowska A., Domiszewski Z., Bienkiewicz G. 2006. Effects of biological and technological factors on the utility of fish as a source of n-3 PUFA. In: Harris R.P. (ed.) Omega3 fatty acids. Nova Science Publishers, New York. (In press)

Lands W.E.M. 1997. Rethink balance between n-3, n-6. Inform 8: 704.

Luten J.B., Martinsdóttir E. 1997. QIM: a European tool for fish freshness evaluation in the fishery chain. pp. 287-300. In: Ólafsdóttir G., Luten J., Daalgard P., Careche M., VerrezBagnis V., Martinsdóttir E., Heia K. (eds.) Methods to determine the freshness of fish in research and industry. Proceedings of the meeting "Evaluation of fish freshness", 12-14 November 1997, Nantes, France.
Ólafsdóttir G., Martinsdóttir E., Oehlenschläger J., Dalgaard P., Jensen B., Undeland I., Mackie I.M., Henehan G., Nielsen J., Nilsen H. 1997. Methods to evaluate fish freshness in research and industry. Trends in Food Science and Technology 8: 258-265.

Özogul Y., Ahmad J.I., Hole M., Özogul F., Deguara S. 2006. The effects of partial replacement of fish meal by vegetable protein sources in the diet of rainbow trout (Oncorhynchus mykiss) on post mortem spoilage of fillets. Food Chemistry 96: 549-561.

Poli B.M., Geri G., Mascini M., Parisi G., Mecatti M., Guidotti P. 1996. Estimate of post mortem loss of fish freshness with biosensor system in rainbow trout (Oncorhynchus mykiss) and sea bass (Dicentrarchus labrax) at different storage temperatures. Pp. 357-361. In: Froid et AquacultureRefrigeration and Aquaculture, 20-22 March 1996, Bordeaux, France.

Regenstein J.M. 1996. Assuring the freshness and quality of aquacultured fish. Pp. 343-362. In: Froid et Aquaculture Refrigeration and Aquaculture, 20-22 March 1996, Bordeaux, France.

Rodríguez C.J., Besteiro I., Pascual C. 1999. Biochemical changes in freshwater rainbow trout (Oncorhynchus mykiss) during chilled storage. Journal of the Science of Food and Agriculture 79: 1473-1480.

Sellner P.A., Hazel J.R. 1982. Distribution and elongation of unsaturated fatty acids in hepatocytes from thermally acclimated rainbow trout. Archives of Biochemistry and Biophysics 213: 58-66.

Sikorski Z.E., Kołakowska A., Burt J.R. 1990. Postharvest biochemical and microbial changes. Pp. 55-76. In: Sikorski Z.E. (ed.) Seafood: resources, nutritional composition and preservation. CRC Press, Boca Raton.

Sikorski Z.E. 2004. Ryby i bezkręgowce morskie. [Marine fish and shellfish.] Wydawnictwo Naukowo-Techniczne, Warszawa. [In Polish.]

Tanimoto S., Hirata T., Sakaguchi M. 1999. The change in content of ATP and its related compounds in freshwater fish muscle during ice storage. Bulletin of the Japanese Society of Scientific Fisheries (Nippon Suisan Gakkaishi) 65 (10): 97-102.
Received: 10 April 2006

Accepted: 7 June 2006 